\title{
Comparative response to nitrogen deficiency of a tropical and temperate grass in the interrelation between photosynthesis, growth, and the accumulation of non-structural carbohydrate
}

\section{J. R. Wilson}

Institute for Biological and Chemical Research on Field Crops and Herbage (IBS), Wageningen, the Netherlands ${ }^{1}$

Accepted: 20 November 1974

\section{Summary}

A tropical grass, Panicum maximum var. trichoglume and a temperate grass, Lolium perenne, were grown in controlled environment rooms at near optimum temperatures of 25 and $18{ }^{\circ} \mathrm{C}$, respectively. After an initial period of growth on full nitrogen nutrient solution, a proportion of the plants of both species were transferred to 'nil' $\mathrm{N}$ nutrient solution. A sequence of destructive harvests was taken as the plants became increasingly $\mathbf{N}$ deficient, and calculations were made of relative growth rate $\left(\mathrm{R}_{W}\right)$, relative leaf area growth rate $\left(\mathrm{R}_{\Lambda}\right)$ and net assimilation rate per unit leaf area $\left(E_{\Lambda}\right)$. On a similarly treated group of plants, net photosynthetic rate $\left(\mathrm{P}_{\mathrm{N}}\right)$ and dark respiration rate of attached leaves were measured.

Organic and nitrate $\mathrm{N}$ were estimated on the photosynthesis-tested leaves, and on comparable leaves from the growth analysis plants at each harvest. Percentage total non-structural carbohydrate (\% TNC) was estimated for $P$. maximum only.

$P$. maximum maintained a higher $\mathrm{R}_{\mathrm{W}}$ and $\mathrm{P}_{\mathrm{N}}$ than $L$. perenne at comparable percent leaf $N$. With increasing $N$ stress, $E_{A}$ of both species declined to a similar relative extent, but $\mathrm{R}_{\mathrm{A}}$ of $P$. maximum decreased much less than that of $L$. peren$n e$. This difference in response to $\mathrm{N}$ between the species in the balance of assimilate input and consumption in new growth may in part explain why under $\mathrm{N}$ deficiency published studies indicate that \% TNC reach higher levels in $L$. perenne and other temperate grasses than in tropical grasses such as $P$. maximum.

\section{Introduction}

Wilson \& Haydock (1971) suggested that at low levels of nitrogen supply, tropical grasses as a group grew relatively better than did temperate grasses. More detailed study (Wilson \& Sandland 1975) confirmed the ability of a tropical grass, Panicum

1 Present address: CSIRO Division of Tropical Agronomy, Cunningham Laboratory, Mill Road, St. Lucia, Qld. 4067, Australia. 
maximum var. trichoglume, to maintain a higher relative growth rate than the subtropically adapted species, Pennisetum clandestinum at low tissue nitrogen concentrations. The purpose of the above studies was to elucidate some of the reasons for the generally low protein content of tropical compared with temperate pasture grasses (e.g. French, 1957). To extend these studies it was considered desirable to make a direct comparison between a tropical and temperate grass in their response to nitrogen. Some aspects of such a comparison are presented here.

Another interesting feature of the comparative physiology of tropical and temperate pasture grasses associated with their growth response to nitrogen is the effect of such treatment on the accumulation of total non-structural carbohydrates. Temperate grasses almost invariably accumulate substantial concentrations of nonstructural carbohydrates under a declining plane of nitrogen nutrition (e.g. Alberda, 1965; Smith, 1973). This effect has been attributed to growth rate being reduced relatively more than photosynthetic rate (Blaser et al., 1966). On a similar argument, the generally small effect of plant nitrogen status on non-structural carbohydrate accumulation in tropical grasses (Balasko \& Smith, 1971; Dovrat et al., 1972; Bessems, 1973; Ford \& Williams, 1973; Lechtenberg et al., 1973; Wilson, $1973,1975)$ may indicate a closer balance in the tropical species between the relative change in growth rate and photosynthetic rate with declining nitrogen supply. The present work examines this point.

A tropical grass, Panicum maximum var. trichoglume, and a temperate grass, Lolium perenne, are compared in their plant growth and leaf photosynthesis characteristics in relation to change in tissue nitrogen concentrations. The paper considers the implications of these responses to accumulation of non-structural carbohydrates.

\section{Methods}

\section{General}

These experiments were carried out in the controlled environment rooms of the IBS at Wageningen, The Netherlands, and details of cultural conditions, growth analysis, photosynthesis measurements and procedures for estimation of nitrogen and total non-structural carbohydrates are given in an earlier paper (Wilson, 1975).

\section{Specific Detail}

Plants of the tropical $\left(\mathrm{C}_{4}\right)$ grass $P$. maximum var. trichoglume cv. Petrie were grown singly from seedlings at $25^{\circ} \mathrm{C}$ in one-litre pots on half-Hoagland's nutrient solution. An initial harvest was taken on day 28 from the sowing of seed. On day 30 , the nutrient solution in one-half the number of pots was replaced by a 'nil' $\mathrm{N}$ nutrient solution (Wilson, 1975) for the remainder of the experiment; these plants were thus exposed to increasing $\mathrm{N}$ stress and became progressively more $\mathrm{N}$ deficient as the experiment progressed. The remainder of the plants continued on halfHoagland's nutrient with frequent solution changes to ensure a high level of $\mathrm{N}$ supply. Harvests of whole plants from the plus $(+N)$ and minus $(-N)$ nitrogen 
treatments (two replicate plants per treatment) were made on days $32,34,36,38$, 40 and 42 from sowing, i.e. after 2, 4, 6, 8, 10 and 12 days of treatment.

Plants of the temperate $\left(\mathrm{C}_{3}\right)$ grass $L$. perenne, vegetatively propagated by tillers from a clone of a tetraploid variety, were grown for about four weeks in halfHoagland's nutrient solution at $18{ }^{\circ} \mathrm{C}$ with two plants per one-litre pot. When the plants were of comparable size to those of $P$. maximum, $+\mathrm{N}$ and $-\mathrm{N}$ treatments were commenced as described above, and harvests of whole plants were taken after $1,4,11,15$ and 18 days of treatment. Plant material from the two plants per pot was bulked at harvest and there were two replicate pots per treatment.

Measurements taken at harvest for both species were total leaf area per plant (excluding dead leaves), with an electronic planimeter, and whole plant dry weight after oven drying for 24 hours at $70^{\circ} \mathrm{C}$. Also, from each plant a separate sample comprising the last fully expanded leaf blade from several main tillers was taken for analysis of nitrate and organic $\mathrm{N}$ content; these leaves were equivalent in development stage to those used for photosynthesis measurements. The whole plant samples of $P$. maximum were analysed for total non-structural carbohydrates (TNC).

Net photosynthetic rate $\left(\mathrm{P}_{\mathrm{N}}\right)$ measurements of attached leaves (two replicate chambers, 6 leaves per chamber) were made as described by Wilson (1975), with for both species an additional group of plants grown concurrently with the plants harvested for growth analysis. Light response curves for $P_{\mathrm{N}}$ were measured for leaves after plants had been exposed to varying numbers of days of nil $\mathrm{N}$ nutrient solution, viz $0,3,6,9$ and 12 days ( $P$. maximum), and $0,3,6,12$ and 18 days (L. perenne); the test temperature was 25 and $18{ }^{\circ} \mathrm{C}$, for the two species, respectively. After each photosynthesis test, the leaf material in the chamber was ovendried and analysed for $\mathrm{N}$ content.

Treatment effects on the basic data are presented and then in Fig. 3 an integrated comparison is made in which growth and photosynthesis parameters for plants of varying degree of $\mathrm{N}$ deficiency are expressed relative to the comparable value for plants under full $\mathrm{N}$ nutrition. For this comparison, the $\mathbf{P}_{\mathrm{N}}$ value for an irradiation level equivalent to that in the growth rooms $\left(70 \mathrm{~J} \mathrm{~m}^{-2} \mathrm{~s}^{-1}\right)$ was determined by interpolation on the light response curves shown in Fig. 2. By interpolation on the growth curves, relative growth rate of whole plants $\left(R_{W}\right)$, relative leaf area growth rate $\left(R_{A}\right)$ and net assimilation rate per unit leaf area $\left(E_{A}\right)$ were derived for each day on which $\mathrm{P}_{\mathrm{N}}$ was measured, i.e. after an equivalent number of days on nil $\mathrm{N}$ solution. The values for the $-\mathrm{N}$ treatments were expressed as a percentage of the value for the $+\mathrm{N}$ treatment on the same day. The data were then plotted on the basis of leaf $\mathrm{N}$ content $(\%)$ of the $-\mathrm{N}$ plants.

\section{Results}

The $+\mathrm{N}$ plants grew vigorously throughout the experiment whereas those on the -N solution became progressively paler green, and many leaves were completely yellow after 12 and 18 days treatment in $P$. maximum and $L$. perenne, respectively. Compared with $L$. perenne, the $\%$ organic $\mathrm{N}$ in leaves of $P$. maximum was lower 


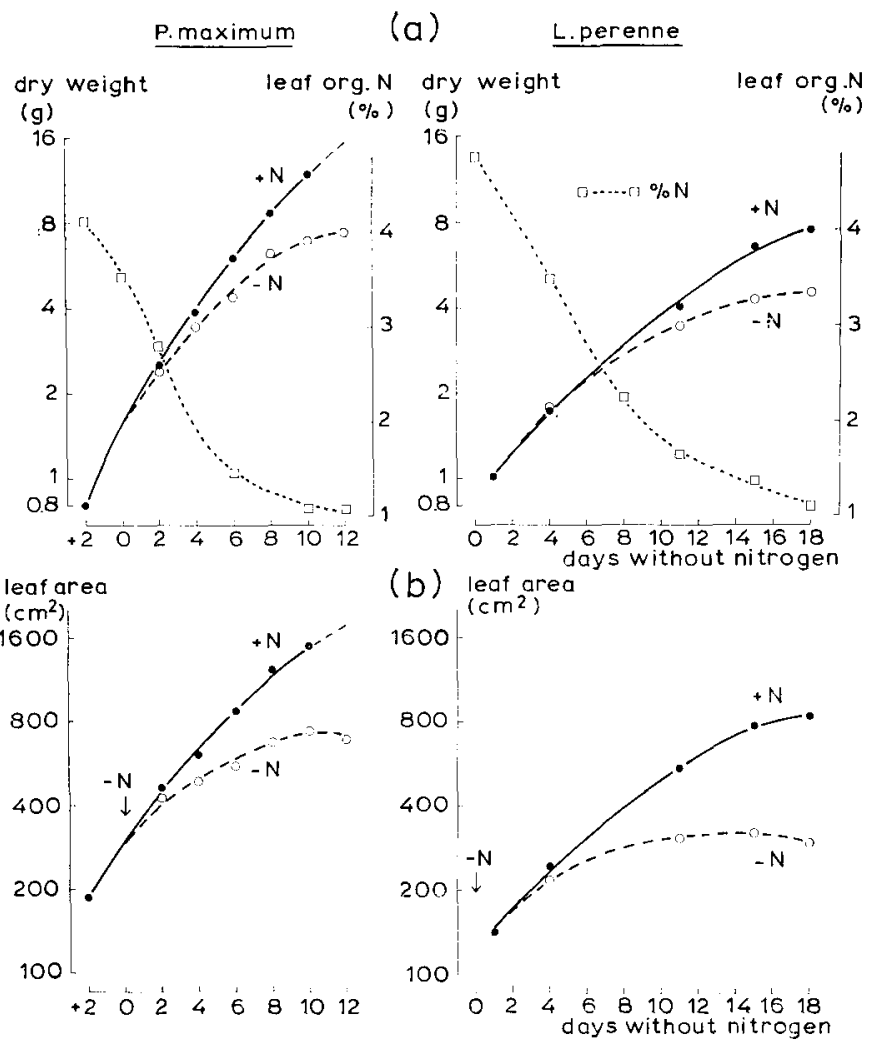

Fig. 1. (a) Whole plant dry weight and (b) total green leaf area per plant, of $P$. maximum and $L$. perenne under high $(+\mathrm{N})$ and declining $(-\mathrm{N})$ nitrogen supply plotted on a logarithm scale. The $\%$ organic $\mathrm{N}$ in leaves of the $-\mathrm{N}$ plants is also shown in (a).

for the $+\mathrm{N}$ plants and declined much more rapidly with time of exposure to $-\mathrm{N}$ solution (Fig. 1).

The $+\mathrm{N}$ plants of $P$. maximum had a higher relative rate of growth of dry weight and area than $L$. perenne (Fig. 1) and this is demonstrated by the average linear regression coefficients with time for log. dry weight $P$. maximum, $0.094>$ $L$. perenne, $0.052(\mathrm{P}<0.001)$ and $\log$. leaf area $P$. maximum, $0.073>L$. perenne $0.046(\mathrm{P}<0.001)$. This species difference was maintained in the $-\mathrm{N}$ treatment although growth rate in both species was markedly reduced $(\mathrm{P}<0.001)$. Nitrogen stress had a relatively more severe effect on rate of leaf area increase than on dry weight increase.

Leaf $\mathrm{P}_{\mathrm{N}}$ of $+\mathrm{N} P$. maximum plants was much higher than that of $L$. perenne (Fig. 2). The $\mathrm{P}_{\mathrm{X}}$ declined progressively in both species with time in $-\mathrm{N}$ solution. The rate of decline was much more rapid in $P$. maximum than in $L$. perenne and as a consequence the rates of $P$. maximum and $L$. perenne were similar, after 9 and 


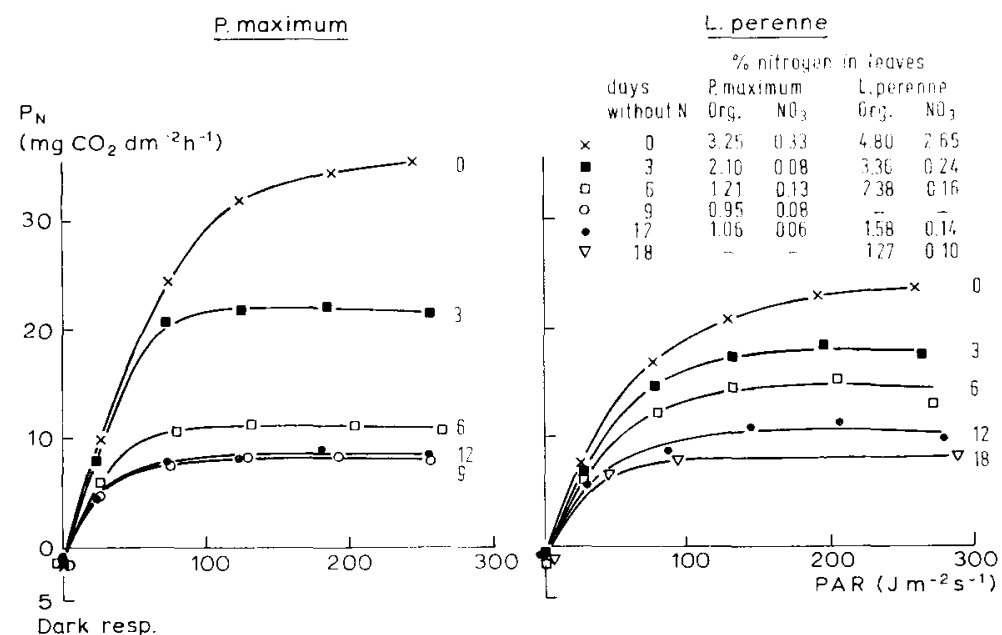

Fig. 2. Net photosynthesis $\left(\mathbf{P}_{\mathrm{N}}\right)$ - photosynthetically active radiation (PAR) response curves of leaves on $P$. maximum and $L$. perenne plants grown for varying number of days on nil $\mathbf{N}$ nutrient solution. Inset shows organic and nitrate $\mathbf{N}$ content $(\%)$ of the leaves.

18 days without nitrogen, respectively. However, $\%$ organic $\mathrm{N}$ content declined to a low value much more rapidly in $P$. maximum than in $L$. perenne, and after 9 days without $\mathrm{N}$ the leaves of $P$. maximum were lower in $\%$ organic $\mathrm{N}$ than those of L. perenne after 18 days treatment (Fig. 2). The $\% \mathrm{NO}_{3}-\mathrm{N}$ in the leaves quickly fell to low values in both species.

Fig. 3 shows the effect of increasing $\mathrm{N}$ stress on the growth and photosynthetic

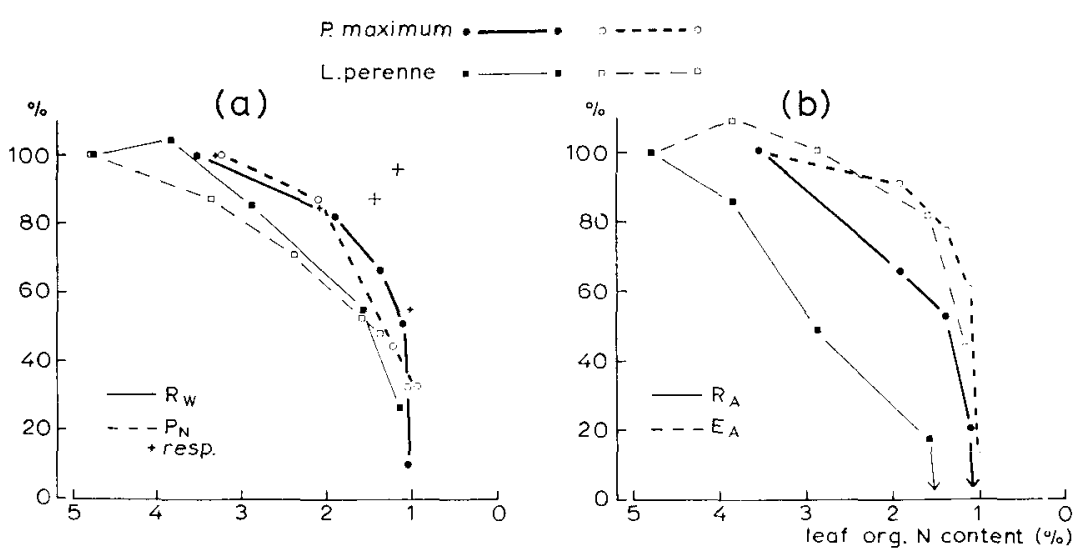

Fig. 3. Comparative effect for $P$. maximum and $L$. perenne of increasing $\mathrm{N}$ deficiency of the -N plants on (a) whole plant relative growth rate $\left(\mathbf{R}_{W}\right)$ and leaf net photosynthesis $\left(\mathbf{P}_{N}\right)$; (b) relative leaf area growth rate $\left(R_{A}\right)$ and net assimilation rate per unit leaf area $\left(E_{A}\right)$. Data expressed relative to the comparable value for the high $\mathrm{N}$ treatment. 
parameters of the $-\mathrm{N}$ plants of each species, with the values expressed relative to the comparable values for the $+N$ treatment. Within either species, $\mathbf{R}_{W}$ and leaf $P_{\mathrm{N}}$ were affected to a similar relative extent by progressive increase in nitrogen stress (Fig. 3a). The decline in these parameters with increasing nitrogen stress, however, was relatively less for $P$. maximum than for $L$. perenne, at least until the plants were severely $\mathrm{N}$ deficient at about $1.0 \%$ leaf organic $\mathrm{N}$ content. A more marked difference between the species is apparent when treatment effects on $E_{A}$ and $R_{\Lambda}$ are considered (Fig. $3 b$ ). Whilst the relative effect of nitrogen stress on $E_{\Lambda}$ was comparable for both species, $R_{\Lambda}$ was much more severly reduced in $L$. perenne than in $P$. maximum and hence the ratio between $\mathrm{E}_{\mathrm{A}}$ and $\mathrm{R}_{\mathrm{A}}$ was much more disturbed in the former species. At the lowest \% leaf organic $\mathrm{N}$, in both species there was an actual loss of green leaf area (Fig. 1), hence the $R_{A}$ values were negative, and the relative values are not plotted in Fig. $3 \mathrm{~b}$.

Dark respiration rate of leaves in $P$. maximum tended to be less affected than $\mathbf{P}_{\mathrm{N}}$ and other growth parameters by increasing nitrogen stress (Fig. 3a). Comparable data for $L$. perenne are not presented on a relative basis because they were variable. The values for $L$. perenne ranged between 0.5 and $1.2 \mathrm{mg} \mathrm{CO}_{2} \mathrm{dm}^{-2} \mathrm{~h}^{-1}$ over the various levels of $\mathrm{N}$ deficiency, with an average of $0.8 \mathrm{mg} \mathrm{CO}_{2} \mathrm{dm}^{-2} \mathrm{~h}^{-1}$. The average value for $P$. maximum was $1.3 \mathrm{mg} \mathrm{CO}_{2} \mathrm{dm}^{-2} \mathrm{~h}^{-1}$.

Nitrogen stress resulted in a small increase $(P<0.01)$ in the \% TNC accumulated by whole plants of $P$. maximum (Table 1 ). The stimulation of carbohydrate accumulation appeared to decline with increasing severity of $\mathrm{N}$ deficiency.

\section{Discussion}

L. perenne was grown at a temperature which from experience was near optimum for this species. Similarly, $P$. maximum was also grown at a temperature near optimum for the present light conditions (Wilson, 1975), although with higher levels of irradiation more active photosynthesis and growth may be achieved at temperature above $25^{\circ} \mathrm{C}$ (Ludlow \& Wilson, 1971). Under these favourable temperature regimes and with good nitrogen nutrition, the $\mathbf{R}_{W}$ of $P$. maximum was considerably higher than that of $L$. perenne, the difference being associated with both higher leaf $\mathrm{P}_{\mathrm{N}}$, and $\mathrm{R}_{\mathrm{A}}$ for $P$. maximum.

Table 1. Effect of nitrogen treatment on the accumulation of total non-structural carbohydrates (TNC) in Panicum maximum.

\begin{tabular}{|c|c|c|c|c|}
\hline \multirow{2}{*}{$\begin{array}{l}\text { Period of } \\
\text { treatment } \\
\text { (days) }\end{array}$} & \multirow{2}{*}{$\begin{array}{l}\text { Nitrogen in } \\
-\mathrm{N} \text { leaves } \\
(\%)\end{array}$} & \multicolumn{2}{|c|}{ TNC } & \multirow{2}{*}{$\begin{array}{l}\text { Relative value } \\
-\mathrm{N} /+\mathrm{N} \\
(\%)\end{array}$} \\
\hline & & $\begin{array}{l}+\mathbf{N} \\
(\%)\end{array}$ & $\begin{array}{l}-\mathbf{N} \\
(\%)\end{array}$ & \\
\hline 2 & 2.80 & 7.3 & 11.2 & 153 \\
\hline 6 & 1.46 & 10.5 & 17.3 & 165 \\
\hline 10 & 1.07 & 9.4 & 11.4 & 121 \\
\hline 12 & 1.05 & 9.0 & 10.3 & 114 \\
\hline
\end{tabular}




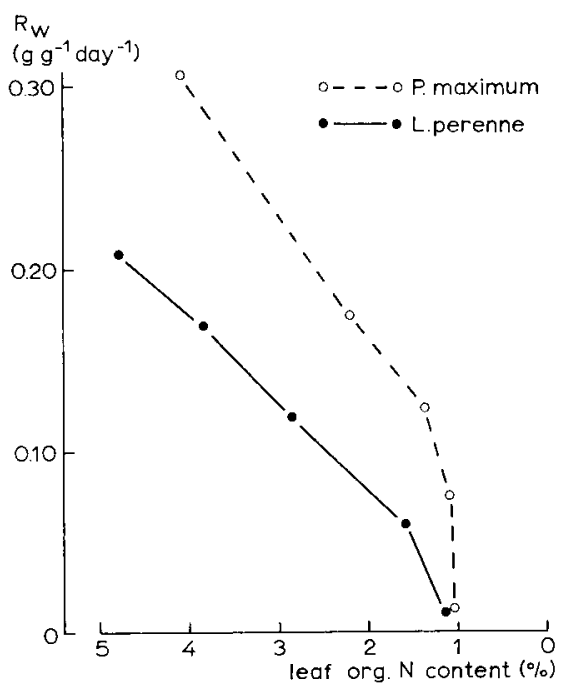

Fig. 4. Relation between plant relative growth rate $\left(\mathbf{R}_{W}\right)$ and leaf organic $\mathbf{N}$ content $(\%)$ for the $-\mathrm{N}$ plants of $P$. maximum and $L$. perenne.

As nitrogen stress was imposed the growth rate of both species declined, but the relative decline in $\mathrm{R}_{\mathrm{W}}$ (Fig. 3) was less for $P$. maximum than for $L$. perenne. Although with severe $\mathrm{N}$ deficiency, as might be expected, the difference between species was reduced. The growth comparison between $P$. maximum and L. perenne when expressed as actual $R_{W}$ plotted against per cent leaf organic $N$ (Fig. 4) was similar to the comparison between $P$. maximum and $P$. clandestinum presented by Wilson \& Sandland (1975). The present data thus extend the conclusions of Wilson and Sandland that the generally low protein content of tropical grasses results in part from their inherent physiological capacity to more efficiently utilize nitrogen. Coupled with this, the high potential $\mathbf{R}_{\mathrm{W}}$ of tropical grasses leads to more rapid exhaustion of available nitrogen, as is clearly evident in this study in the rapid decline of per cent leaf organic $\mathbf{N}$ to very low values in the $P$. maximum plants used for the photosynthesis tests (Fig. 2).

The basis for the growth advantage of the $-\mathrm{N}$ plants of $P$. maximum over those of $L$. perenne appears to lie largely in the lesser effect of $\mathrm{N}$ deficiency on $\mathrm{R}_{\mathrm{A}}$ in the former species. Leaf $\mathrm{P}_{\mathrm{N}}$ in $P$. maximum was also less affected by increasing $\mathrm{N}$ stress than that of $L$. perenne but this advantage was offset by the apparently higher dark respiration rate of $P$. maximum. As a consequence, the net input of assimilates per unit leaf area per day, $E_{A}$, was affected by $N$ stress to the same relative extent in both species (Fig. 3). The assimilates, however, were more effectively distributed to achieve continuing productive potential via leaf area expansion in $P$. maximum. This would agree with the general observation from a wider range of species, that over varying levels of applied $\mathrm{N}$, a higher top/root ratio was maintained in tropical than in temperate grasses (Wilson \& Haydock, 1971). 
These species differences in growth response to increasing $\mathrm{N}$ deficiency have significant implications for the accumulation of carbohydrate reserves. Whilst the assimilatory capacity of both species, viz $\mathbf{E}_{\Lambda}$, was affected to a similar relative extent by $\mathrm{N}$ deficiency, $P$. maximum continued to channel assimilates into new leaf area production much more effectively than did $L$. perenne. Consequently, the relative excess of assimilates above those consumed in growth was likely to be much lower for $P$. maximum and indeed the actual increase in TNC in this species with increasing $\mathrm{N}$ deficiency was small (Table 1). Levels of TNC were not measured for $L$. perenne because very detailed studies using the same variety, controlled environment facilities, and irradiation level, were made by Alberda (1965). These studies revealed accumulation of TNC up to 25-35\% of dry weight in leaves from plants grown at $15-20{ }^{\circ} \mathrm{C}$ under increasing $\mathrm{N}$ deficiency and at tissue $\mathrm{NO}_{3}-\mathrm{N}$ percentages comparable to the lower values for $L$. perenne in the present work. Further research on $L$. perenne and other temperate grasses, reviewed by Smith (1973), support these findings.

There is little evidence to suggest that the use of other growth temperatures would obviate the difference between $P$. maximum and $L$. perenne in TNC accumulation under $\mathrm{N}$ deficiency. A previous study (Wilson, 1975) indicates that the level of $\mathrm{TNC}$ in low $\mathrm{N}$ plants of $P$. maximum is relatively insensitive to change in temperature. On the other hand, the data of Alberda (1965) do indicate that for $L$. perenne the \% TNC accumulated under $\mathrm{N}$ deficiency decreases with higher growth temperature. At the temperature at which $P$. maximum was grown in this experiment, viz $25^{\circ} \mathrm{C}$, the TNC in leaves of $L$. perenne was up to 17-24\% of dry weight, and in stubble up to $30 \%$. These values are still higher than the 10-11\% TNC in the severely deficient plants of $P$. maximum (Table 1). At temperatures below the $18{ }^{\circ} \mathrm{C}$ used here for L. perenne, TNC increased up to $40 \%$ of dry weight in the plants of Alberda (1965).

An additional factor influencing the accumulation of TNC in $P$. maximum associated with high $\mathbf{R}_{W}$, was the more rapid decline in $N$ status of this species compared with $L$. perenne. A critical state of $\mathrm{N}$ deficiency was reached in 9 days in $P$. maximum but took 18 days in $L$. perenne. There is some evidence from Table 1 and from previous work (Wilson, 1973) that in $P$. maximum some TNC tends to accumulate under moderate $\mathrm{N}$ deficiency but not when $\mathrm{N}$ deficiency is severe. This might perhaps be expected because at values less than $1.4 \%$ organic $\mathrm{N}$ for the most recently expanded leaf of $P$. maximum, the rate of assimilate input $\left(E_{A}\right)$ declined abruptly. This may be not so evident from $P_{N}$ but this measurement was made on the youngest expanded leaf and older leaves would be significantly more deficient in nitrogen. The growth parameters for $L$. perenne showed trends similar to those for $P$. maximum but because $\mathrm{N}$ deficiency developed more slowly, this species had a longer period in which to accumulate reserve carbohydrate.

\section{Acknowledgments}

I wish to thank Dr E. M. Hutton, Chief, CSIRO, Division of Tropical Agronomy, Brisbane, Australia, and Dr Th. Alberda, Deputy Director, IBS, Wageningen, The 
Netherlands, for their co-operation in providing the opportunity and facilities for this research. I also wish to thank Dr Alberda for his helpful advice during this work. I extend my appreciation to Mrs Janny Witlage and Miss Margreet Geurtsen for their help with the experiments, and to the staff of the IBS for the chemical analyses and photosynthesis measurements.

\section{References}

Alberda, Th., 1965. The influence of temperature, light intensity and nitrate concentration on dry-matter production and chemical composition of Lolium perenne L. Neth. J. agric. Sci. 13: 335-360.

Balasko, J. A. \& D. Smith, 1971. Influence of temperature and nitrogen fertilization on the growth and composition of Switchgrass (Panicum virgatum L.) and Timothy (Phleum pratense L.) at anthesis. Agron. J. 63: 853-857.

Bessems, E. P. M., 1973. Nitrogen fixation in the phyllosphere of Gramineae. Agric. Res. Rep. 786, Wageningen, pp. 1-68.

Blaser, R. E., R. H. Brown \& H. T. Bryant, 1966. The relationship between carbohydrate accumulation and growth of grass under different microclimates. Proc. 10th int. Grassld Congr. (Helsinki): 147-150.

Dovrat, A., B. Deinum \& J. G. P. Dirven, 1972. The influence of defoliation and nitrogen on the regrowth of Rhodes grass (Chloris gayana Kunth) 2 . Etiolated growth and non-structural carbohydrate, total-N and nitrate-N content. Neth. J. agric. Sci. 20: 97-103.

Ford, C. W. \& W. T. Williams, 1973. In vitro digestibility and carbohydrate composition of Digitaria decumbens and Setaria anceps grown at different levels of nitrogen fertilizer. Aust. J. agric. Res. 24: 309-316.

French, M. H., 1957. Nutritional value of tropical grasses and fodders. Herb. Abstr. 27: 1-9.

Lechtenberg, V. L., D. A. Holt \& H. W. Youngberg, 1973 Diurnal variation in non-structural carbohydrates of Sorghum sudanense (Stapf.) as influenced by environment. Agron. J. 65: 579-583.

Ludlow, M. M. \& G. L. Wilson, 1971. Photosynthesis of tropical pasture plants. II. Temperature illuminance history. Aust. J. biol. Sci. 24: 1065-1075.

Smith, D., 1973. The non-structural carbohydrates. In: G. W. Butler \& R. W. Bailey (Ed.), Chemistry and biochemistry of herbage, Vol. 1: 106-155. Academic Press, London.

Wilson, J. R., 1973. The influence of aerial environment, nitrogen supply, and ontogenetical changes on the chemical composition and digestibility of Panicum maximum Jacq. var. trichoglume Eyles. Aust. J. agric. Res. 24: 543-556.

Wilson, J. R., 1975. Influence of temperature and nitrogen on growth, photosynthesis and accumulation of non-structural carbohydrate in a tropical grass, Panicum maximum var. trichoglume. Neth. J. agric. Sci. 23: 48-61.

Wilson, J. R. and K. P. Haydock, 1971. The comparative response of tropical and temperate grasses to varying levels of nitrogen and phosphorus nutrition. Aust. J. agric. Res. 22: 573587.

Wilson, J. R. \& R. L. Sandland, 1975. The relation between growth and nitrogen and phosphorus content of green panic and kikuyu grass. Pl. Soil (in press). 